\title{
THE INFLUENCE OF NATURA 2000 SITES ON THE INVESTMENT ATTRACTIVENESS OF POLISH REGIONS
}

\author{
Katarzyna PAWLEWICZ, Department of Real Estate Resources, University of Warmia and Mazury, Plac Lodzki 2, 10-727, Olsztyn, \\ Poland, katarzyna.pawlewicz@uwm.edu.pl (corresponding author) \\ Adam PAWLEWICZ, Department of Agrotechnology, Agricultural Production Management and Agribusiness, University of \\ Warmia and Mazury, Plac Lodzki 2, 10-727 Olsztyn, Poland, adampawl@uwm.edu.pl, \\ Iwona CIEŚLAK, Institute of Geoinformation and Cartography, University of Warmia and Mazury, Plac Lodzki 2, 10-727Olsztyn, \\ Poland, isidor@uwm.edu.pl
}

This article evaluates the influence of the Natura 2000 network (N2K) of protected areas on the investment attractiveness of Polish regions. Natura 2000 sites were analyzed with the use of the Technique for Order Preference by Similarity to Ideal Solution (TOPSIS), a linear ordering method with a common pattern and anti-pattern of development, and correlation analysis (Pearson's correlation coefficient). The basic unit of analysis was the county (Polish: powiat, the second-level unit of local government and administration in Poland). Poland is divided into 16 regions (known as voivodeships) with a total of 380 counties. The results of the analysis were used to determine synthetic values describing the level and potential of investment attractiveness in Polish counties, and the strength of correlations between the evaluated phenomena. Indicators of investment attractiveness of Polish counties were selected based on published data and analyzed in view of several criteria: labor resources, technical infrastructure, social infrastructure, market support and administrative support. The correlations between the investment attractiveness of Polish counties and the presence of N2K sites in those counties were analyzed statistically. Data for analysis were acquired from the Local Data Bank of the Central Statistical Office. The analysis revealed that the presence of $\mathrm{N} 2 \mathrm{~K}$ sites in the examined territorial units does not significantly influence their investment attractiveness.

Keywords: Natura 2000 sites, Polish regions, socioeconomic development, TOPSIS

\section{INTRODUCTION}

Investments are one of the key determinants of stable economic growth. In a market economy, a favorable investment climate significantly influences a region's ability to attract investors (Strzelczyk, 2015). The investment climate is the institutional, policy, and regulatory environment in which firms operate. In developing locations that create a good governance and business environment, returns and accumulation should be high (Dollar et al. 2005). The investment climate is closely correlated with investment attractiveness which is defined as a region's ability to attract new residents (or migrants), tourists, businesses, investments and investors, as well as the ability to preserve high levels of social and economic growth and the existing resources (Raczyk et al. 2010; Russo et al. 2012). Investment attractiveness should be regarded as an integrated indicator which promotes investments in a given area. It encompasses a set of local resources which increase the probability of investment success (Godlewska-Majkowska, 2010). Investment success is determined mainly by the natural, physical and geographic features of a given area. However, due to the progress of civilization in various areas, such as technology and infrastructure, the features which contribute to investment success are largely determined by the local investment policy (United Nations, 2015).

The natural environment and environmental protection laws can significantly influence a region's economic growth and investment attractiveness. Nature conservation areas are established within the existing legal framework. Protected areas are meant for natural and cultural heritage complexes, ecological balance and biodiversity conservation, restoration of natural resources. They also create conditions for cognitive rest, research as well as environment protection and ethno-cultural education (Gurskis, Zujavičienè 2015). However, the presence of protected areas can considerably limit the extent of potential investments. Environmental concerns play an increasingly important role in policy-making and the economic and social development strategies at various levels of governance. These concerns have led to the creation of the Natura 2000 network (N2K) of protected areas in the European Union.

In Poland, the process of establishing N2K sites began in 2004 when Poland joined the European Union. Protected areas are usually created in regions characterized by high forest cover, low population, nutrient-poor soils,

Copyright (C) 2017 The Authors. Published by Aleksandras Stulginskis University. This is an open-access article distributed under the terms of the Creative Commons Attribution License (CC-BY 4.0), which permits unrestricted use, distribution, and reproduction in any medium, provided the original author and source are credited. 
low levels of infrastructure and low entrepreneurship (Boltromiuk, 2012). The Natura 2000 network is rarely seen as an element of Poland's socioeconomic development strategy, and it is generally regarded as yet another regulatory measure that limits the use of public space and prevents private owners from exercising the rights to their property (Hoyos et al. 2012). However, areas of outstanding natural values do not always directly inhibit the development of territorial units; in fact, they can exert a stimulating influence on local growth (Getzner, Jungmeier, 2002; Pawlewicz et al. 2015).

In this study, the tested research hypothesis states that investment attractiveness is influenced by the accumulation of $\mathrm{N} 2 \mathrm{~K}$ sites within the administrative boundaries of territorial units. The strength of such correlations varies in areas characterized by heterogeneous development, and contrary to popular belief, the observed relationships are directly proportional. Therefore, the presence of N2K sites can exert both stimulating and destimulating effects on economic growth and, consequently, the investment attractiveness of a territorial unit. The aim of this study was to evaluate the influence of N2K sites on the investment attractiveness of Polish regions. The research hypothesis was tested with the use of the Technique for Order of Preference by Similarity to Ideal Solution (TOPSIS), a linear ordering method with a common pattern and anti-pattern of development, and correlation analysis (Pearson's correlation coefficient). The basic unit of analysis was the county (Polish: powiat, the second-level unit of local government and administration in Poland). Poland is divided into 16 regions (known as voivodeships) with a total of 380 counties. The results of the analysis were used to determine synthetic values describing the level and potential of investment attractiveness in Polish counties, and the strength of correlations between the area of N2K sites, investment attractiveness and various criteria of investment attractiveness.

\section{RESEARCH METHODS}

Two types of counties were analyzed in this study: nature $(\mathrm{N})$ counties with $\mathrm{N} 2 \mathrm{~K}$ sites on their territory, and non-nature (NN) counties without N2K sites on their territory.

The following analytical procedure was adopted:

I. The percentage share of N2K sites was determined in each Polish county. The analysis was conducted based on data acquired from the Partnership System for Managing Economic Change in N2K Sites (http://www.natura2000.efort.pl/, access: 20.09.2014). In view of the area occupied by N2K sites, the counties were divided into 5 classes based on arithmetic mean and standard deviation values, where class I denotes counties with a high percentage of $\mathrm{N} 2 \mathrm{~K}$ sites, and class $\mathrm{V}$ is represented by counties without $\mathrm{N} 2 \mathrm{~K}$ sites.

II. Indicators of investment attractiveness of Polish counties were selected based on published data (Swianiewicz, Dziemianowicz, 1998; Raczyk et al. 2010; Godlewska-Majkowska, 2010; Nowicki et al., 2015) and analyzed in view of various attractiveness criteria: labor resources, technical infrastructure, social infrastructure, market support and administrative support. Data for analysis were acquired from the Local Data Bank of the Central Statistical Office in Warsaw.

III. Excessively correlated criteria of investment attractiveness were eliminated. The diagonal elements of the invertible correlation matrix were analyzed, and excessively correlated variables with values higher than 10 on the main diagonal were eliminated. A total of 32 indicators were used in further analysis.

IV. The investment attractiveness of Polish counties was determined with the use of the TOPSIS method (Technique for Order Preference by Similarity to an Ideal Solution) (Hwang, Yoon, 1981, Wysocki, 2010 , Huang et al. 2011, Tzneng, Huang 2011) by calculating the Euclidean distance separating every evaluated object (county) from the pattern (positive ideal solution) and anti-pattern (negative ideal solution). The resulting synthetic indicators were used to rank the evaluated objects. The best object was characterized by the shortest distance from the pattern of development and the longest distance from the anti-pattern of development (Hwang, Yoon, 1981, Wysocki, 2010, Huang et al. 2011, Tzneng, Huang 2011).

V. The correlations between the synthetic indicator of investment attractiveness (and attractiveness criteria) and the area occupied by N2K sites in counties in every Polish region were determined by calculating the Pearson's correlation coefficient in the Statistica program.

\section{RESEARCH RESULTS}

Natura 2000 sites occupy around 20\% of Poland's territory. The following Polish regions are characterized by the highest percentage of N2K sites: Zachodnie Pomorze (34\%), Podkarpacie (30\%), Podlasie (27\%), Warmia and Mazury (24\%) and Dolny Slask (21\%). The percentage of N2K sites is lowest in the regions of Kujawy and Pomorze (4\%), Lodz (3\%) and Opole (2\%). Polish counties differ significantly in the percentage of territory occupied by N2K sites. In some cases, N2K sites occupy more than $90 \%$ of a county's territory. In the total number of 380 Polish counties, only $22.4 \%$ did not feature any N2K sites. The spatial distribution of N2K sites in Polish counties is presented in Figure 1.

The TOPSIS method was used to rank Polish counties based on their investment attractiveness (and attractiveness criteria). The counties were divided into N2K classes in accordance with the described procedure. The results are presented in Table 1, and the spatial distribution of investment attractiveness and attractiveness criteria is presented in Figure 1. 
Table 1. Ranking of Polish counties based their investment attractiveness evaluated with the use of the TOPSIS method.

\begin{tabular}{|c|c|c|c|c|c|c|c|c|c|c|c|}
\hline \multirow{4}{*}{ 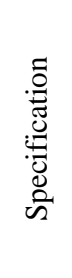 } & \multicolumn{2}{|c|}{ Class I } & \multicolumn{2}{|c|}{ Class II } & \multicolumn{2}{|c|}{ Class III } & \multicolumn{2}{|c|}{ Class IV } & \multirow{2}{*}{\multicolumn{2}{|c|}{ Total }} & \multirow{4}{*}{ స్త్రి } \\
\hline & \multicolumn{2}{|c|}{$\begin{array}{l}\text { High investment } \\
\text { attractiveness }\end{array}$} & \multicolumn{2}{|c|}{$\begin{array}{l}\text { Moderate-high } \\
\text { investment } \\
\text { attractiveness }\end{array}$} & \multicolumn{2}{|c|}{$\begin{array}{l}\text { Moderate-low } \\
\text { investment } \\
\text { attractiveness }\end{array}$} & \multicolumn{2}{|c|}{$\begin{array}{l}\text { Low investment } \\
\text { attractiveness }\end{array}$} & & & \\
\hline & $\mathrm{N}$ & $\mathrm{NN}$ & $\mathrm{N}$ & $\mathrm{NN}$ & $\mathrm{N}$ & $\mathrm{NN}$ & $\mathrm{N}$ & $\mathrm{NN}$ & \multirow[b]{2}{*}{$\begin{array}{l}\mathrm{N} \\
\text { No. }\end{array}$} & \multirow[b]{2}{*}{$\begin{array}{l}\text { NN } \\
\text { No. }\end{array}$} & \\
\hline & $\begin{array}{l}\text { No. } \\
(\%)\end{array}$ & $\begin{array}{l}\text { No. } \\
(\%)\end{array}$ & $\begin{array}{l}\text { No. } \\
(\%)\end{array}$ & $\begin{array}{l}\text { No. } \\
(\%)\end{array}$ & $\begin{array}{l}\text { No. } \\
(\%)\end{array}$ & $\begin{array}{l}\text { No. } \\
(\%)\end{array}$ & $\begin{array}{l}\text { No. } \\
(\%)\end{array}$ & $\begin{array}{l}\text { No. } \\
(\%)\end{array}$ & & & \\
\hline IA & $52(17.6)$ & $\begin{array}{c}28 \\
(32.9)\end{array}$ & $\begin{array}{c}31 \\
(10.5)\end{array}$ & $\begin{array}{c}16 \\
(18.8)\end{array}$ & $\begin{array}{c}108 \\
(36.6)\end{array}$ & $\begin{array}{c}22 \\
(25.9)\end{array}$ & $\begin{array}{c}104 \\
(35.3)\end{array}$ & $\begin{array}{c}19 \\
(22.4)\end{array}$ & \multirow{6}{*}{295} & \multirow{6}{*}{85} & \multirow{6}{*}{380} \\
\hline LR & $61(20.7)$ & $\begin{array}{c}14 \\
(16.5)\end{array}$ & $\begin{array}{c}78 \\
(26.4)\end{array}$ & $\begin{array}{c}29 \\
(34.1)\end{array}$ & $\begin{array}{c}89 \\
(30.2)\end{array}$ & $\begin{array}{c}18 \\
(21.2)\end{array}$ & $\begin{array}{c}67 \\
(22.7)\end{array}$ & $\begin{array}{c}24 \\
(28.2)\end{array}$ & & & \\
\hline $\mathrm{TI}$ & $37(12.5)$ & $\begin{array}{c}36 \\
(42.4) \\
\end{array}$ & $\begin{array}{c}28 \\
(9.5) \\
\end{array}$ & $\begin{array}{c}10 \\
(11.8) \\
\end{array}$ & $\begin{array}{c}126 \\
(42.7) \\
\end{array}$ & $\begin{array}{c}23 \\
(27.0) \\
\end{array}$ & $\begin{array}{c}104 \\
(35.3) \\
\end{array}$ & $\begin{array}{c}16 \\
(18.8) \\
\end{array}$ & & & \\
\hline SI & 55 (18.6) & $\begin{array}{c}15 \\
(17.6) \\
\end{array}$ & $\begin{array}{c}84 \\
(28.5) \\
\end{array}$ & $\begin{array}{c}25 \\
(29.4) \\
\end{array}$ & $\begin{array}{c}113 \\
(38.3) \\
\end{array}$ & $\begin{array}{c}31 \\
(36.5) \\
\end{array}$ & $\begin{array}{c}43 \\
(14.6) \\
\end{array}$ & $\begin{array}{c}14 \\
(16.5) \\
\end{array}$ & & & \\
\hline MR & $40(13.6)$ & $\begin{array}{c}38 \\
(44.7) \\
\end{array}$ & $\begin{array}{c}62 \\
(21.0) \\
\end{array}$ & $\begin{array}{c}12 \\
(14.1) \\
\end{array}$ & $\begin{array}{c}105 \\
(35.6) \\
\end{array}$ & $\begin{array}{c}19 \\
(22.4) \\
\end{array}$ & $\begin{array}{c}88 \\
(29.8) \\
\end{array}$ & $\begin{array}{c}16 \\
(18.8) \\
\end{array}$ & & & \\
\hline $\mathrm{AS}$ & $65(22.0)$ & $\begin{array}{c}17 \\
(20.0)\end{array}$ & $\begin{array}{c}51 \\
(17.3)\end{array}$ & $\begin{array}{c}25 \\
(29.4)\end{array}$ & $\begin{array}{c}84 \\
(28.5)\end{array}$ & $\begin{array}{c}19 \\
(22.4)\end{array}$ & $\begin{array}{c}95 \\
(32.2)\end{array}$ & $\begin{array}{c}24 \\
(28.2)\end{array}$ & & & \\
\hline
\end{tabular}

Key: $\mathrm{N}$ - Nature counties with $\mathrm{N} 2 \mathrm{~K}$ sites, NN - Non-nature counties without N2K sites

IA - investment attractiveness; LR - labor resources; TI - technical infrastructure; SI - social infrastructure; MR - market support; AS - administrative support

Source: own elaboration based on the Local Data Bank of the Central Statistical Office.
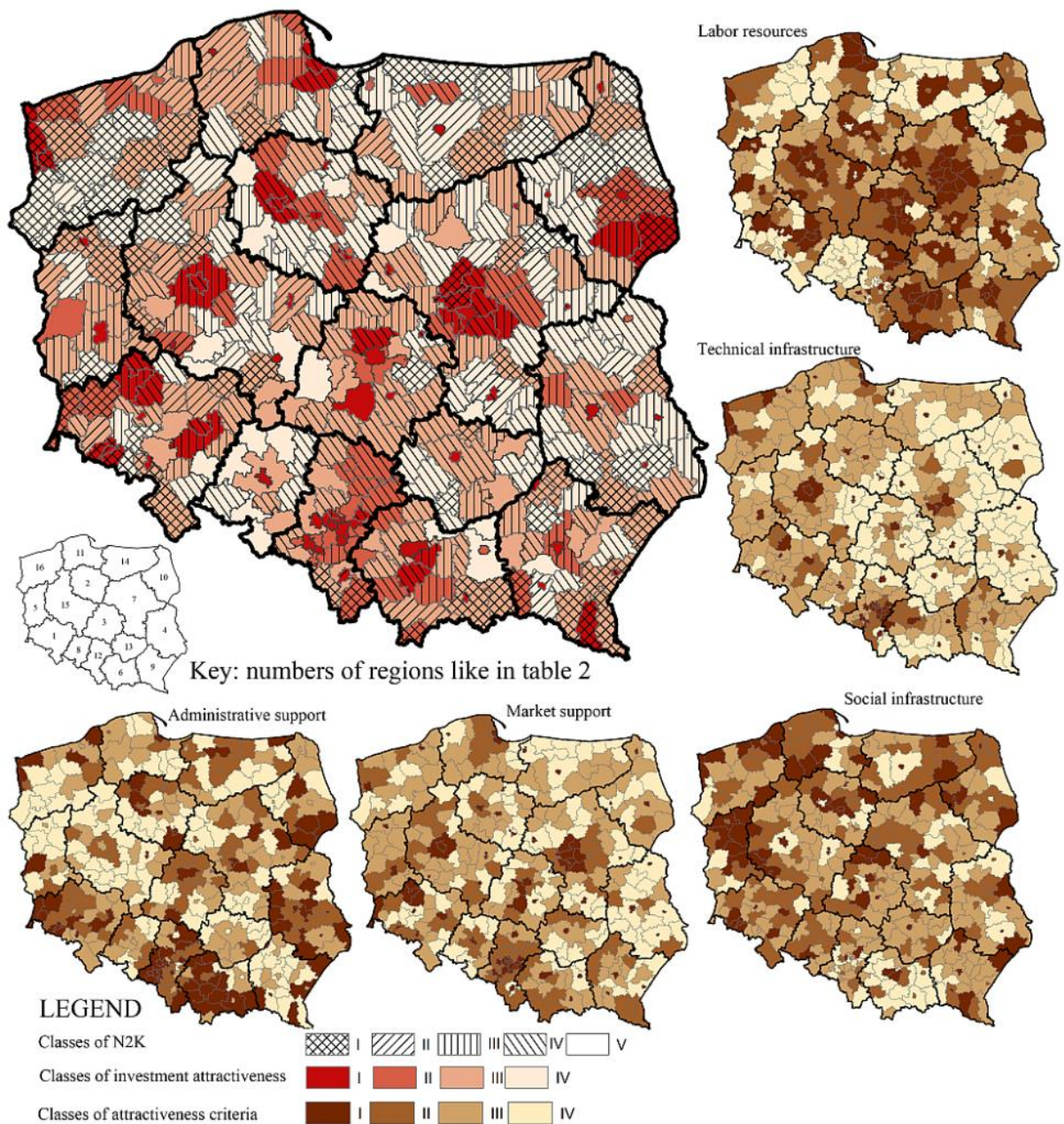

Classes of attractiveness criteria $\quad \square \quad$ I $\square$ ॥ $\square$ III $\square$ IV

Figure 1. Spatial distribution of Polish counties belonging to different N2K classes and spatial distribution of investment attractiveness and attractiveness criteria.

Source: own elaboration

An analysis of the investment attractiveness of Polish counties revealed that class I was composed of $52 \mathrm{~N}$ counties (highly attractive for investors), which accounted for $17.6 \%$ of all $\mathrm{N}$ counties, and $28 \mathrm{NN}$ counties which accounted for $32.9 \%$ of all NN counties (the highest result for NN counties) (table 2). Most class I counties were urban counties and regional business hubs. The surrounding counties were also characterized by high levels of investment attractiveness. 
Class II (counties with moderate-high levels of investment attractiveness) was composed of $31 \mathrm{~N}$ counties $(10 \%$ of all $\mathrm{N}$ counties) and $16 \mathrm{NN}$ counties (18.8\% of all NN counties). Class III (counties with moderate-low levels of investment attractiveness) was the largest group which comprised $108 \mathrm{~N}$ counties (36.6\% of all $\mathrm{N}$ counties) and $22 \mathrm{NN}$ counties ( $25.9 \%$ of all $\mathrm{NN}$ counties). Class IV (counties with low levels of investment attractiveness) was also relatively large and consisted of $104 \mathrm{~N}$ counties (35.2\% of all N counties) and $19 \mathrm{NN}$ counties (22.4\% of all NN counties). These results indicate that Poland is moderately attractive for potential investors.

Linear correlations were not observed between the area occupied by $\mathrm{N} 2 \mathrm{~K}$ sites in counties and the investment attractiveness of Polish counties. The above results indicate that the presence and the area occupied by N2K sites in the analyzed counties do not influence Poland's overall attractiveness for investors. Significant correlations were noted only in the category of labor resources $(r=-0.13 ; \mathrm{p}<0.05)$, technical infrastructure $(r=-0.11 ; \mathrm{p}<0.05)$ and social infrastructure $(\mathrm{r}=0.11 ; \mathrm{p}<0.05)$, but the noted values were too low to suggest the presence of linear correlations.

The area occupied by $\mathrm{N} 2 \mathrm{~K}$ sites influenced the investment attractiveness of two Polish regions. A moderate negative correlation was observed in Lubuskie Region ( $\mathrm{r}=-0.52 ; \mathrm{p}<0.05)$ where N2K sites occupied $23 \%$ of the region's total area. A reverse trend was noted in the Region of Kujawy and Pomorze whose investment attractiveness improved with an increase in the percentage of $\mathrm{N} 2 \mathrm{~K}$ sites $(\mathrm{r}=0.51 ; \mathrm{p}<0.05)$. However, N2K sites accounted for only $4 \%$ of the region's total area. The above suggests that investment attractiveness is influenced by other factors and that the small area occupied by $\mathrm{N} 2 \mathrm{~K}$ sites does not impinge on economic growth despite the presence of a positive correlation.

The presence of negative correlations in the labor resources category was observed in two regions with a small share of N2K sites. A strong correlation was noted in the Region of Opole $(r=-0.89 ; \mathrm{p}<0.05)$ which is characterized by the lowest percentage of N2K sites in Poland (2\%). Natura 2000 sites are found in only 4 out of the 12 counties of the Region of Opole; therefore, the observed correlation is not a simple causal relationship. A moderate negative correlation was also found in the Region of Lodz ( $\mathrm{r}=-0.54 \mathrm{p}<0.05)$. Lodz is one of the most highly developed Polish regions in the labor resources category. Labor resources were most abundant in class II counties, both N and NB. However, N2K sites accounted for only $3 \%$ of the total area of the Lodz Region.

A moderate positive correlation was noted in the Region of Zachodnie Pomorze $(r=0.45$; $\mathrm{p}<0.05)$ which is characterized by the highest share of N2K sites in Poland (34\%). Natura 2000 sites were absent in only 1 out of the 21 counties of Zachodnie Pomorze (labor resources in class IV), and occupied more than 26\% of the territory in 14 counties. Agriculture and industrial production are the main sources of income in Zachodnie Pomorze where primeval forests and protected areas have outstanding natural and economic value.

In some Polish regions, N2K sites also influenced technical infrastructure. A statistically significant, moderate negative correlation was observed in the Region of Podkarpacie $(r=-0.49$; $\mathrm{p}<0.05)$ where the share of $\mathrm{N} 2 \mathrm{~K}$ sites was determined at $30 \%$. Natura 2000 sites were identified in 18 out of the 25 counties of Podkarpacie, and their share of local territory varied considerably from $1 \%$ to $72 \%$. In the Region of Kujawy and Pomorze, a moderate improvement in the availability of technical infrastructure was observed with an increase in the area occupied by N2K sites $(r=0.54 ; \mathrm{p}<0.05)$.

In the Region of Zachodnie Pomorze, technical infrastructure was also correlated with the share of N2K sites $(\mathrm{r}=0.45 ; \mathrm{p}<0.05)$. However, only $12.5 \%$ of $\mathrm{N}$ counties were grouped in class I (urban counties and their neighbours). In most of these counties, the share of $\mathrm{N} 2 \mathrm{~K}$ sites did not exceed $26 \%$. The only exceptions were the urban counties of Swinoujscie and Szczecin and the county of Police which was characterized by a high share of N2K sites as well as high levels of infrastructure development (more than $40 \%$ in NN counties). The availability of infrastructure was higher in urban agglomerations and suburban areas, and it was lower in $\mathrm{N}$ counties, most of which were assigned to class III (42.7\%) and class IV (35.3\%). The above results indicate that infrastructure development is more likely to be influenced by a county's status rather than the presence of $\mathrm{N} 2 \mathrm{~K}$ sites.

The share of $\mathrm{N} 2 \mathrm{~K}$ sites in Polish regions did not influence social infrastructure. A relatively strong correlation $(\mathrm{r}=0.71 ; \mathrm{p}<0.05)$ was noted only in the Region of Lodz. As previously mentioned, Lodz has a small share of N2K sites, and social infrastructure levels vary considerably across its counties.

The value of the "market support" variable decreased with an increase in the area occupied by N2K sites in selected regions. A statistically significant, moderately strong correlation was noted in the Region of $\operatorname{Lodz}(r=-0.61 ; \mathrm{p}<0.05)$, and the obtained result was contrary to that noted in the social infrastructure category. Moderate correlations between market support and investment attractiveness were also observed in Lubuskie Region $(r=-0.50 ; \mathrm{p}<0.05)$ and in the Region of Pomorze $(\mathrm{r}=-0.41 ; \mathrm{p}<0.05)$. However, market support levels in Pomorze varied considerably across counties, and the share of $\mathrm{N} 2 \mathrm{~K}$ sites in counties ranged from less than $1 \%$ to $28 \%$ (regional average of $11 \%$ ).

A reverse trend was observed in the Region of Kujawy and Pomorze where a moderate increase in market support was noted with an increase in the area occupied by N2K sites $(r=0.53 ; p<0.05)$.

Administrative support was not correlated with the investment attractiveness of Polish regions. 
Table 2. The strength of correlations (Pearson's correlation coefficient) between the investment attractiveness of Polish counties, attractiveness criteria and the share of $\mathrm{N} 2 \mathrm{~K}$ sites.

\begin{tabular}{|c|c|c|c|c|c|c|c|}
\hline Specification & 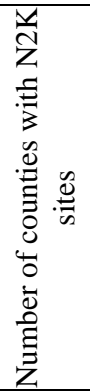 & 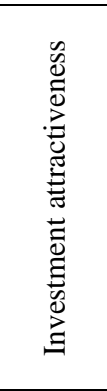 & 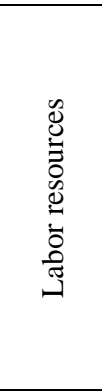 & 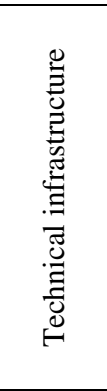 & 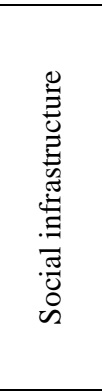 & 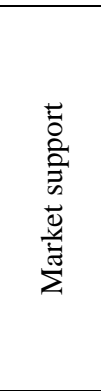 & 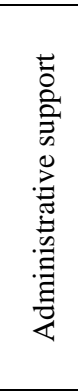 \\
\hline \multicolumn{8}{|c|}{ Share of N2K sites (Pearson's correlation coefficient at a significance level of $\mathrm{p}<0.05$ ) } \\
\hline POLAND & 295 & -0.10 & $-0.13 *$ & $-0.11 *$ & $0.11 *$ & -0.08 & -0.02 \\
\hline DOLNY SLASK (1) & 28 & -0.18 & -0.30 & -0.28 & 0.05 & -0.09 & 0.07 \\
\hline KUJAWY AND POMORZE (2) & 20 & $0,51 *$ & -0.04 & $0.54 *$ & 0.38 & $0.53 *$ & 0.38 \\
\hline LODZ (3) & 14 & -0.43 & $-0,54 *$ & -0.39 & $0.71 *$ & $-0.61 *$ & 0.03 \\
\hline LUBELSKIE (4) & 20 & -0.09 & -0.31 & -0.22 & 0.20 & -0.23 & -0.05 \\
\hline LUBUSKIE (5) & 13 & $-0.52 *$ & -0.24 & -0.41 & -0.01 & $-0.50 *$ & -0.08 \\
\hline MALOPOLSKA (6) & 15 & -0.29 & -0.08 & -0.21 & -0.002 & 0.05 & -0.24 \\
\hline MAZOWSZE (7) & 37 & -0.16 & -0.10 & -0.21 & -0.08 & -0.10 & 0.14 \\
\hline OPOLSKIE (8) & 4 & 0.50 & $-0.89 *$ & 0.09 & 0.53 & 0.58 & 0.71 \\
\hline PODKARPCIE (9) & 18 & -0.04 & -0.09 & $-0.49^{*}$ & 0.13 & -0.07 & 0.06 \\
\hline PODLASIE (10) & 15 & 0.09 & 0.43 & -0.08 & -0.09 & -0.15 & 0.25 \\
\hline POMORZE (11) & 19 & -0.38 & -0.16 & -0.40 & 0.21 & $-0.41 *$ & -0.04 \\
\hline SLASK (12) & 15 & -0.04 & -0.03 & -0.18 & -0.02 & 0.08 & 0.08 \\
\hline SWIETOKRZYSKIE (13) & 11 & 0.32 & -0.40 & 0.24 & 0.49 & 0.41 & -0.18 \\
\hline WARMINA AND MAZURY (14) & 19 & -0.29 & -0.29 & -0.30 & 0.13 & -0.06 & -0.37 \\
\hline WIELKOPOLSKIE (15) & 27 & -0.10 & -0.10 & -0.23 & 0.25 & -0.13 & 0.30 \\
\hline ZACHODNIE POMORZE (16) & 20 & 0.35 & $0.45 *$ & $0.45^{*}$ & -0.001 & 0.25 & -0.01 \\
\hline
\end{tabular}

* correlation coefficient significant at 0.05

Source: own elaboration

\section{CONCLUSIONS AND DISCUSSION}

The presence of $\mathrm{N} 2 \mathrm{~K}$ sites can have a potentially limiting impact on a given area's attractiveness for investors. However, most foreign investments in Poland originate from countries with restrictive environmental protection laws. For this reason, environmental protection should not be regarded as a barrier to investment. Since Poland joined the European Union, regions with a steadily increasing share of $\mathrm{N} 2 \mathrm{~K}$ sites have been growing as dynamically as regions where N2K sites had not been established, and the values of socioeconomic indicators have changed only in a limited number of cases. These observations suggest that local communities are able to harness the opportunities arising from nature conservation, such as organic farming and environmentally-friendly tourism, which minimizes potential conflict. However, the economic benefits of $\mathrm{N} 2 \mathrm{~K}$ sites are difficult to extrapolate because the evaluated regions differ in economic structure, demographics and economic growth.

Interestingly, significant correlations between the existence of $\mathrm{N} 2 \mathrm{~K}$ sites and the criteria of investment attractiveness were observed in regions with a low share of $\mathrm{N} 2 \mathrm{~K}$ areas, including in the Region of Lodz and the Region of Kujawy and Pomorze, where significant correlations were noted in three analyses. Two negative correlations and one positive correlation were observed in Lodz, whereas in Kujawy and Pomorze, all three significant correlations were positive. The results of the analysis also indicate that investment attractiveness is more likely to be influenced by a county's status (urban counties are more attractive) and location (suburban areas) than the share of N2K sites.

In the regions of Lubuskie and Zachodnie Pomorze, which are characterized by a high share of N2K sites, correlations were observed in only two categories. In Lubuskie Region, all correlations were negative, whereas in Zachodnie Pomorze, which has the highest share of N2K sites in Poland, all correlations were positive.

It can be concluded that the presence of $\mathrm{N} 2 \mathrm{~K}$ sites in the examined territorial units does not influence the socioeconomic development of Polish counties. The above conclusion could help mitigate social conflicts that arise upon the establishment of new N2K sites, and abolish the myth that nature conservation poses a barrier to socioeconomic growth. Our findings also provide valuable inputs for the network managing authority and could be used to identify areas where the creation of $\mathrm{N} 2 \mathrm{~K}$ sites does not contribute to local development. The managing authority could rely on the results of this study to propose solutions that reconcile local development with the protection of valuable areas. The creation of N2K sites could be one of such incentives, but it is unlikely to generate the desired levels of economic growth on its own.

\section{REFERENCES}

1. Boltromiuk, A. 2012. Natura 2000 - The opportunities and dilemmas of the rural development within European Ecological Network. Problems of Sustainable Development, Vol. 7, No. 1, pp. 117-128 
2. Dollar, D., Hallward-Driemeier, M., Mengistae, T. 2005. Investment climate and firm performance in developing economies. Economic Development and Cultural Change, Vol. 54, Iss. 1, pp. 1-31. https://doi.org/10.1086/431262

3. Getzner, M., Jungmeier, M. 2002. Conservation policy and the regional economy: the regional economic impact of Natura 2000 conservation sites in Austria. Journal for Nature Conservation, Vol. 10, Iss. 1, pp. 25-34.https://doi.org/10.1078/1617-1381-00003

4. Godlewska-Majkowska, H. 2010. Investment attractiveness of Polish regions 2010 - synthesis. Kolegium Nauk o Przedsiebiorstwie SGH, Warszawa. [In Polis]

5. Gurskis, V., Zujavičienè, V. 2015. Influence of buildings exterior on the landscape of the Nemunas Delta Regional Park. Proceedings of the 7th International Scientific Conference "Rural Development 2015". Lithuanian University of Agriculture. https://doi.org/10.15544/RD.2015.051

6. Hoyos, D., Mariel, P., Pascual, U., Etxano, I. 2012. Valuing a Natura 2000 network site to inform land use options using a discrete choice experiment: An illustration from the Basque Country. Journal of Forest Economics, Vol. 18, Iss. 4, pp. 329-344. https://doi.org/10.1016/j.jfe.2012.05.002

7. Huang, I.B., Keisler, J., Linkov, I. 2011. Multi-Criteria Decision Analysis in Environmental Sciences: Ten Years of Applications and Trends. Science of The Total Environment, Vol. 409, Iss. 19, pp. 3578-3594. https://doi.org/10.1016/j.scitotenv.2011.06.022

8. Hwang, C.L., Yoon, K. 1981. Multiple Attribute Decision Making: Methods and Applications, A State of The Art Survey. Berlin, Heidelberg, New York: Springer-Verlag. https://doi.org/10.1007/978-3-642-48318-9

9. Nowicki, M., Susmarski, P., Tarkowski (ed.), M., Wandalowski, M., Wozniak, W. 2015. The Investment Attractiveness of the Regions And The Sub-Regions of Poland. The Gdansk Institute For Market Economics. Gdansk.

10. Pawlewicz, A., Cieslak, I., Pawlewicz, K., Szuniewicz, K. 2015. Natura 2000 Sites and socio-economic development of rural communes in Eastern Poland. Proceedings of the 2015 International Conference "Economic Science for Rural Development 2015". Vol. 38, pp. 14-23.

11. Raczyk, A., Dolzblasz, S., Lesniak-Johann, M. 2010. Analiza atrakcyjnosci inwestycyjnej regionu w swietle wspolczesnych trendow. Dolnoslaska Agencja Wspolpracy Gospodarczej. Wroclaw. [In Polis]

12. Russo, A.P., I. Smith, R. Atkinson, L. Servillo, B. Madsen, Otgaar A. 2012. The Attractiveness of European regions and cities for residents and visitors. ESPON: Final Report of the ATTREG project. ESPON \& University Rovira i Virgili.

13. Strzelczyk, W. 2015. Investment attractiveness measurement of the regions and versus general location of the enterprises. Economic and Regional Studies, Vol. 7, Iss. 2, pp. 5-25.

14. Tzneng, G.H., Huang, J.J. 2011. Multiple Attribute Decision Making Methods and applications. Taylor \& Francis Group, LLC

15. United Nations. 2015. Investment policy framework for sustainable development.

16. Wysocki, F. 2010. Metody taksonomiczne w rozpoznawaniu typow ekonomicznych rolnictwa i obszarow wiejskich. Poznan: Uniwersytet Przyrodniczy. [In Polis] 